\title{
Effect of Flow and Dissolved Oxygen on the Compatibility of Pongamia pinnata Biodiesel with Common Construction Materials Used in Storage and Transportation
}

\author{
H. N. Meenakshi ${ }^{1}$ and R. Shyamala ${ }^{2}$ \\ ${ }^{1}$ Centre for Emerging Technologies, Jain University, Jakkasandra Post, Kanakapura Taluk, Ramanagara District, Bangalore, \\ Karnataka 562 112, India \\ ${ }^{2}$ Department of Chemistry, Avinashilingam Institute for Home Science and Higher Education for Women, Coimbatore, \\ Tamil Nadu 641 043, India
}

Correspondence should be addressed to H. N. Meenakshi; meenaparam75@gmail.com

Received 8 July 2015; Revised 30 September 2015; Accepted 21 October 2015

Academic Editor: Iftekhar A. Karimi

Copyright (C) 2015 H. N. Meenakshi and R. Shyamala. This is an open access article distributed under the Creative Commons Attribution License, which permits unrestricted use, distribution, and reproduction in any medium, provided the original work is properly cited.

\begin{abstract}
The compatibility of Pongamia pinnata biodiesel (PBD) and its $\mathrm{NaCl}$ blends on aluminium, brass, copper, carbon steel, and mild steel has been studied by static mass loss and rotating cage methods. The effects of dissolved oxygen and flow on the metal corrosion in PBD were also observed. This study confirmed that the copper strip test alone is not enough to determine the fuel property since the corrosion of ferrous metal was found to be high in PBD compared to other metals. The least corrosion rate of aluminium was confirmed by surface morphology and elemental analysis.
\end{abstract}

\section{Introduction}

Vegetable oils have become more attractive as substitute for traditional fossil fuels because of their environmental benefits and the fact that they are made from renewable resources. The consumption of edible oil is very high in the country and still the indigenous production does not meet the demand and considerable amount of edible oil is imported and it is therefore not advisable to divert these sources for biodiesel production. On the other hand, the nonedible oil resources can be a solution for biodiesel production [1-3]. Pongamia pinnata, Jatropha curcas, and other trees of nonedible grade native to humid and subtropical environments can be grown on degraded and marginal land. Among these, Pongamia pinnata is an untapped resource for the biodiesel [4]. It is anticipated that by planting Pongamia on roadsides, on riverbanks, and on the two sides of irrigation canals, India will able to produce several million tons of biodiesel in near future.

Biodiesel is produced by reacting vegetable oil or animal fat with an alcohol, usually methanol by the transesterification reaction [5-7]. This process brings the properties of the raw materials closer to those of conventional petroleum diesel. Fatty acid methyl ester (FAME) can be used neat as a fuel but is more commonly blended with petroleum diesel for use in diesel engines [8-10]. Various metals are used to handle biodiesel during the storage, transportation, combustion, and automobile operational conditions [11-13]. Regardless of how well the infrastructure is maintained, biodiesel may be contaminated with water at various stages. In general, biodiesel attracts water more than petroleum diesel. The corrosive effect of biodiesel is mainly caused by the presence of water. Water in biodiesel can promote unwanted microbiological growth, which may lead to filter blocking and corrosion [1416]. Water can support hydrolytic reactions, breaking down the FAME to form free fatty acids. Such species are corrosive and may attack exposed metal surfaces. A number of different effects may be involved (changes in TAN value, increased water content, oxidation product, presence of metals species, changes in structural features of biodiesel component, etc.) in making the situation more complicated [17-19]. Therefore 


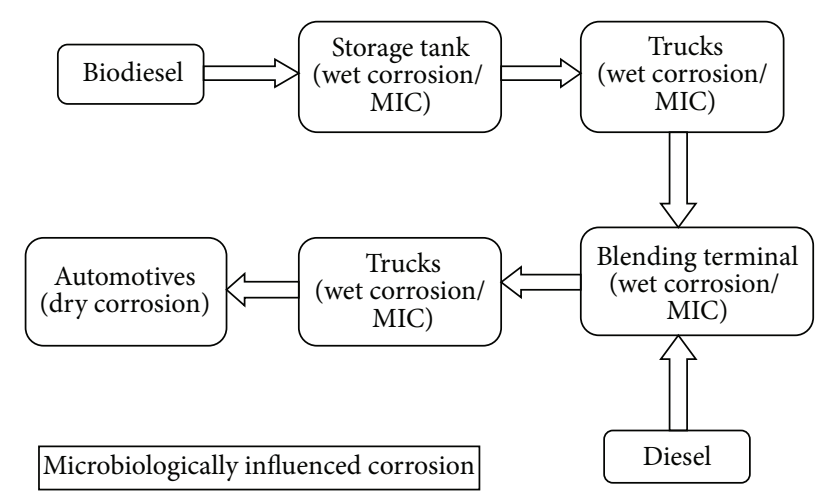

Figure 1: Corrosion types and locations.

it is important to understand the biodiesel-materials interaction in various stages (production, storage, transportation, and usage). Figure 1 presents the corrosion types and their locations in storage and transportation of biodiesel.

The corrosivity of water in the presence of biodiesel depends on the composition of the fuel. In general, depending on how well it affects corrosivity of the water phase, the biodiesel may broadly be classified into (a) protective, (b) inhibitive, (c) neutral, and (d) corrosive ones. This classification is based on the evaluation of wettability, emulsion tendency, and corrosion rate [20]. It should be understood that emulsion and wettability are two different properties. Biodiesel may hold a lot of water, but as soon as the inversion point occurs, the surface may become water-wet immediately. On the other hand, an inversion point may occur at a very low water cut, but the surface may not become waterwet until a very high water cut is reached. The difference in behavior is due to the fact that the emulsion depends on liquid-liquid (oil-water) interaction whereas wettability depends on the balance between two solid-liquid (metaloil and metal-water) interactions. Corrosivity of water phase becomes significant only in the presence of either oil in water emulsion or free water and on a water-wet or mixedwet surface. The factor responsible for one property may or may not influence other properties. For this reason, all three properties (emulsion, wettability, and corrosivity) should be determined independently.

Any part of the biodiesel supply system needs to be assessed for materials compatibility and may need to be refitted with materials that are resistant to the effects of biodiesel. Currently used indicators of corrosiveness of biodiesel, for example, copper strip corrosion and TAN value that are prescribed by different standards, are not effective enough and corrosive nature of biodiesel under wide spectrum of compositional, environmental, and operating variables should be investigated. Hence in this investigation the corrosion rates of five metals (aluminium, brass, copper, carbon steel, and mild steel) in PBD were studied by static mass loss and rotating cage methods. Static mass loss is used to depict storage condition and rotating cage is used to simulate pipeline flow under laboratory conditions by rotating the specimens at speeds up to $1500 \mathrm{rpm}$ [21]. The corrosivity of
TABLE 1: Composition, density, and equivalent weight of the materials.

\begin{tabular}{lccc}
\hline Element & \multicolumn{3}{c}{ \% composition } \\
& Aluminium & Carbon steel & Mild steel \\
\hline $\mathrm{Zn}$ & 0.009 & - & - \\
$\mathrm{Al}$ & $\mathbf{9 8 . 6 6}$ & - & 0.023 \\
$\mathrm{Sn}$ & - & - & $<0.005$ \\
$\mathrm{~Pb}$ & 0.002 & - & $<0.010$ \\
$\mathrm{Si}$ & 0.47 & 0.011 & 0.018 \\
$\mathrm{Ni}$ & $<0.005$ & 0.008 & 0.014 \\
$\mathrm{Fe}$ & 0.69 & 99.6 & 99.56 \\
$\mathrm{Mn}$ & 0.092 & 0.222 & 0.27 \\
$\mathrm{P}$ & - & 0.030 & 0.009 \\
$\mathrm{~S}$ & - & 0.026 & 0.005 \\
$\mathrm{Bi}$ & $<0.010$ & - & - \\
$\mathrm{Sb}$ & - & - & - \\
$\mathrm{Cu}$ & 0.023 & - & 0.030 \\
$\mathrm{Cr}$ & 0.007 & 0.003 & 0.019 \\
$\mathrm{C}$ & - & 0.120 & 0.049 \\
$\mathrm{Mo}$ & - & 0.035 & 0.002 \\
$\mathrm{Density}\left(\mathrm{g} / \mathrm{cm}^{3}\right)$ & 2.73 & 7.87 & 7.87 \\
Equivalent weight & 9.09 & 27.92 & 27.92 \\
\hline
\end{tabular}

PBD for different metals is analyzed by rotating cage method in the presence and absence of oxygen to study the effect of dissolved oxygen.

\section{Materials and Methods}

2.1. Biodiesel Procurement and Characterization. PBD was collected from a commercial company in Coimbatore, India, and characterized by FT-IR using a Bio-Rad Excalibur Model FTS3000MX in the range $4000-600 \mathrm{~cm}^{-1}$. Biodiesel can be used in neat form or blended with petroleum diesel for use in compression ignition (diesel) engines. Its physical and chemical properties as it relates to operation of diesel engines are similar to petroleum based diesel fuel. Therefore PBD used for the present investigation was examined for various physicochemical characteristics as per American Standards for Testing and Materials (ASTM D6751) in a testing laboratory.

2.2. Selection of Metals. The most common construction metals used for tankers, storage tanks, pipes, and pumping equipment are carbon steel, stainless steel, aluminum, and copper alloys. Hence aluminium, copper, brass, carbon steel, and mild steel were chosen for the present investigation. Commercially available metal sheets machined into coupons of area $33.9 \mathrm{~cm}^{2}$ (ASTM G184) were used for the entire study. The elemental compositions of brass and copper are given elsewhere [22]; aluminium and ferrous metals are presented in Table 1. 
The following test media were used for the present investigation:

(i) $\mathrm{B} 100 \rightarrow 100 \%$ biodiesel (pure biodiesel),

(ii) $\mathrm{NaCl} \rightarrow 3 \%$ (w/v) sodium chloride,

(iii) $\mathrm{B} 99 \rightarrow 1 \mathrm{~mL}$ of $3(\mathrm{w} / \mathrm{v}) \% \mathrm{NaCl}+99 \%$ biodiesel $(99 \mathrm{~mL}$ biodiesel) to prepare $100 \mathrm{~mL}$ solution.

The $3 \% \mathrm{NaCl}$ is considered to represent water contamination, because at this concentration highest corrosion rate of carbon steel has been observed [23].

2.3. Wettability. The presence of free water or of o/w emulsion does not necessarily lead to corrosion. Under this condition, wettability of the biodiesel on the metal determines corrosivity. The wettability of PBD on various metals was studied by contact angle method and detailed discussion has been given in previous publication [24], the significance of which is detailed elsewhere [20].

2.4. Emulsion Inversion Point. Emulsion inversion point (EIP) was determined by measuring the conductivity of the solution. Test solution was placed in an electromagnetic stirrer and continuously stirred for 20 minutes to obtain standard emulsion. The conductivity was measured at 2-minute interval and data were averaged. These steps were repeated for different biodiesel/ $\mathrm{NaCl}$ ratios, starting with $100 \%$ of biodiesel (B100) and progressively increasing the water content $(3 \%$ $\mathrm{NaCl})$ in steps $(90 \mathrm{~mL} \mathrm{B100}+10 \mathrm{~mL}$ of $3 \% \mathrm{NaCl}, 80 \mathrm{~mL}$ $\mathrm{B} 100+20 \mathrm{~mL}$ of $3 \% \mathrm{NaCl}$ until $0 \mathrm{~mL} \mathrm{~B} 100+100 \mathrm{~mL}$ of $3 \%$ $\mathrm{NaCl}$ was reached). From the plot of conductance versus biodiesel/ $\mathrm{NaCl}$ ratio, EIP was determined for PBD.

\subsection{Corrosion Rate Measurement}

2.5.1. Static Mass Loss Method. As per ASTM G1 the metal coupons were immersed in triplicate in $200 \mathrm{~mL}$ of various test media for a period of $100 \mathrm{~h}$. Specimens were removed after the set intervals of time and wiped with trichloroethylene for the removal of the excess fuel. Then aluminum coupons were dipped in concentrated nitric acid for $5 \mathrm{~min}$ and steel coupons in solution containing $500 \mathrm{~mL}$ con. $\mathrm{HCl}$ and $3.5 \mathrm{~g}$ hexamethylenetetramine for $10 \mathrm{~min}$ as per ASTM G1-90. The coupons were then washed with distilled water, dried, and reweighed. The loss in mass was determined. From the mass loss the corrosion rates were calculated and average results from three specimens are reported.

2.5.2. Rotating Cage. Rotating cage used for the experiments has been fabricated as per ASTM G184. The acrylic vessel was filled with 4 litres of test solution. The metal samples were held between two Teflon holders, which have been designed to hold eight coupons. Experiments were conducted for a period of $100 \mathrm{~h}$ at the rotation speed of $500 \mathrm{rpm}$. The description of rotating cage and experimental procedure was explained elsewhere [22]. The corrosion rate was calculated from the difference in mass of the coupons. To study the effect of dissolved oxygen at the emulsion inversion point, rotating cage experiments were carried out at deaerated condition.
This condition was achieved by purging nitrogen to the solution at the rate of four bubbles per second for a period of four hours and maintained the blanket throughout the experiment. The following formula has been used to calculate the corrosion rate in Mils per year (mpy):

$$
\begin{aligned}
& \text { Corrosion Rate (mpy) } \\
& =\frac{3.45 \times 10^{6} \times \text { Mass loss }(\text { grams })}{\text { Density }\left(\mathrm{g} / \mathrm{cm}^{3}\right) \times \text { Area }\left(\mathrm{cm}^{2}\right) \times \text { Time (hours) }} .
\end{aligned}
$$

2.6. Scanning Electron Microscopy. The surface morphology and the elemental composition of the corrosion products were determined by JEOL, JSM-6390 Scanning Electron Microscope (SEM) equipped with a light element energydispersive X-ray detector (EDX) for composition analysis in and away from the corrosion pits. Secondary electron images were collected along with EDX spectra.

\section{Results and Discussion}

\subsection{Characterization of Pongamia pinnata Biodiesel}

3.1.1. FT-IR Analysis. The FT-IR spectra in the midinfrared region are used to identify the functional groups and the bands corresponding to various stretching and bending vibrations in $\mathrm{PBD}$ and the spectra are given in Figure 2. Biodiesel kinds are basically esters which have two characteristically strong absorption bands arising from carbonyl $(\nu$ $\mathrm{C}=\mathrm{O}$ ) around $1750-1730 \mathrm{~cm}^{-1}$ and that of $\mathrm{C}-\mathrm{O}$ (antisymmetric axial stretching and asymmetric axial stretching) at 1300$1000 \mathrm{~cm}^{-1}[25,26]$. The position of carbonyl group in FTIR is sensitive to substituent effects and to the structure of the molecule. The possible structures obtained from FT-IR spectrum search are the alkyl group, a carboxylic acid ester, long chain aliphatic esters, and carbonyl compounds. In the spectra, peaks in the $1000-900 \mathrm{~cm}^{-1}$ region are assigned to symmetric angular deformation (out of plane) of the $\mathrm{C}-\mathrm{H}$ bonds of olefins, peaks around $1200 \mathrm{~cm}^{-1}$ are assigned to the asymmetric stretching band of $\mathrm{C}-\mathrm{C}(\mathrm{O})-\mathrm{O}$ bonds of the ester group, and peaks $1180-1200 \mathrm{~cm}^{-1}$ are assigned to the asymmetric stretching band of $\mathrm{O}-\mathrm{C}-\mathrm{C}$ bonds. Since biodiesel is mainly monoalkyl ester, the intense $\mathrm{C}=\mathrm{O}$ stretching band of methyl ester appears at $1743 \mathrm{~cm}^{-1}$ for Pongamia biodiesel.

3.1.2. Physicochemical Characteristics. The Biodiesel Association of Canada defines biodiesel as follows: "The monoalkyl esters of long-chain fatty acids that are derived from fats and oils that meets the specification of ASTM D6751 and EN 14214 or any legal successor thereto" [27]. The ASTM standards for diesel, biodiesel, and measured parameters for PBD as per ASTM D6751 are presented in Table 2. The observation of each fuel property of PBD is explained in detail.

Flash Point. The flash point is the minimum temperature at which the fuel will ignite on application of an ignition source under specified conditions. The flash point of biodiesel should be at least $130^{\circ} \mathrm{C}$, and in general it is higher than that of diesel fuels having a flash point of at least $52^{\circ} \mathrm{C}$. The 
TABLE 2: ASTM standards for diesel, biodiesel, and fuel properties of PBD.

\begin{tabular}{|c|c|c|c|c|}
\hline Parameters & ASTM D975 & ASTM D6751 & PBD & Unit \\
\hline Flash point & $52 \mathrm{~min}$ & $130.0 \mathrm{~min}$ & 126 & ${ }^{\circ} \mathrm{C}$ \\
\hline Water content and sediment & $0.050 \max$ & $0.050 \max$ & 0.0322 & $\%$ vol \\
\hline Kinematic viscosity $40^{\circ} \mathrm{C}$ & $1.9-4.1$ & $1.9-6.0$ & 6.06 & $\mathrm{~mm}^{2} / \mathrm{sec}$ \\
\hline Sulfated ash & $0.01 \max$ & $0.020 \max$ & 0.01 & $\%$ mass \\
\hline Sulfur (grade number 2, low sulfur/S 500 grade) & $0.05 \max$ & $0.05 \max$ & 0.0013 & $\%$ mass \\
\hline Copper strip corrosion & Number 3 max & Number 3 max & 2 & - \\
\hline Cetane & $40 \mathrm{~min}$ & $47 \mathrm{~min}$ & 62.0 & - \\
\hline Carbon residue & $0.35 \max$ & $0.050 \max$ & 0.02 & $\%$ mass \\
\hline Acid number & - & $0.80 \max$ & 0.3 & $\mathrm{Mg} \mathrm{KOH} / \mathrm{g}$ \\
\hline Free glycerin & - & $0.020 \max$ & 0.01 & $\%$ mass \\
\hline Total glycerin & - & $0.240 \max$ & 0.12 & $\%$ mass \\
\hline Phosphorous contents & - & $0.001 \max$ & 0.0001 & $\%$ mass \\
\hline Distillation temperature, atmospheric equivalent temperature, $90 \%$ recovered & $282-338$ & $360 \max$ & 242 & ${ }^{\circ} \mathrm{C}$ \\
\hline Aromaticity & $35 \max$ & - & - & $\%$ vol. \\
\hline
\end{tabular}

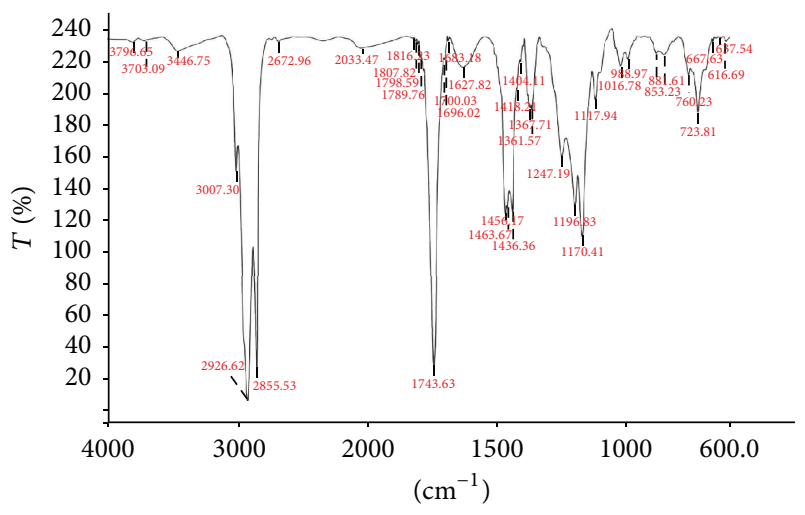

FIgURe 2: FT-IR spectra of Pongamia pinnata biodiesel.

flash point of $\mathrm{PBD}$ is reported as $126^{\circ} \mathrm{C}$, higher than that of the conventional diesel. Hence storing biodiesel is safe as compared to storing diesel [28].

Water Content and Sediment. The presence of water and sediment generally indicates poor fuel handling practices. Water in the sample can promote microbial growth, lead to tank corrosion, participate in the formation of emulsions, and cause hydrolysis or hydrolytic oxidation [29]. It is evident from Table 2 that water and sediment content of PBD (0.0322\%) is well within limits specified by standard.

Kinematic Viscosity. Higher viscosity of a fuel causes poor fuel atomization during spray, increases the engine deposits, needs more energy to pump the fuel, and wears fuel pump elements and injectors. This also causes more problems in cold weather, because viscosity increases with decreasing temperatures. The ASTM has prescribed an acceptable kinematic viscosity at $40^{\circ} \mathrm{C}$ for biodiesel to be $1.9-6.0 \mathrm{~mm}^{2} / \mathrm{sec}$. The viscosity of $\mathrm{PBD}$ is $6.06 \mathrm{~mm}^{2} / \mathrm{sec}$, which is very close to the ASTM D6751 standard value.
Sulfated Ash. Sulfated ash content describes the amount of inorganic contaminants. ASTM D6751 mentions that the biodiesel samples can have a maximum $0.02 \%$ sulfated ash. As evident in table, the sulfated ash of PBD is found to be $0.01 \%$, which is well within the limits of ASTM specification.

Sulfur Content. Presence of sulfur in the fuel will lead to the formation of $\mathrm{SO}_{2}$ and $\mathrm{SO}_{3}$, which are corrosive gases that might corrode the engine parts. The ASTM standard approved maximum sulfur content for biodiesel of $0.05 \%$ which was fulfilled by PBD (0.013\%).

Copper Strip Corrosion. The copper strip corrosion test consists of dipping a strip of copper into the fuel for a specified time and defined temperature to observe the corrosive action of the fuel. The degree of tarnish on the corroded strip correlates with the overall corrosiveness of the fuel sample. ASTM certifies copper strip corrosion value for biodiesel to be 3 maximum. The copper strip corrosion property of the investigated biodiesel was found to be 2, well within the specifications of ASTM D6751.

Cetane Number. The cetane number is a dimensionless descriptor of the ignition quality of a fuel. Generally, higher cetane number causes significant reductions in the $\mathrm{NO}_{x}$ emissions due to shorter ignition delay times and the resulting lower average combustion temperatures. In the present analysis the cetane index was found to be 62 for PBD. The higher cetane number is due to the increase in carbon chain length.

Carbon Residue. In fuels, the carbon residue is the part remaining after a sample is subjected to thermal decomposition and it indicates coking tendency. The maximum limit for carbon residue in biodiesel is $0.050 \%$ by mass. A carbon residue value of Pongamia biodiesel was $0.02 \%$ mass and successfully meets the ASTM standards. 
Acid Number. The acid number is a measure of acidic substance in the biodiesel. It is used as a guide in the quality control as well as monitoring biodiesel degradation during storage. The lowest acid number was obtained for PBD $(0.3 \mathrm{mg} \mathrm{KOH} / \mathrm{g})$. Acid number of biodiesel is $0.5 \mathrm{mg} \mathrm{KOH} / \mathrm{g}$ specified as the maximum value according to ASTM D6751 which was fulfilled by Pongamia biodiesel. The acid number can become a serious issue, when feed stocks with high free fatty acids are used to produce biodiesel.

Total and Free Glycerin. Fuel with excessive free glycerol can result in material incompatibility, engine deposits, and combustion problems in the engine. The free glycerol content of a biodiesel should not exceed $0.020 \%$ by mass and the maximum amount of total glycerol should be $0.240 \%$ by mass. Free and total glycerol contents are within the standard requirement (0.01 and 0.12), respectively, for PBD.

Phosphorous Content. The influence of phosphorous is cumulative; therefore even very low levels of its contamination may lead to unexpected deterioration of the system. For Pongamia biodiesel, the amount of phosphorous is found to be $0.0005 \%$ by mass, which is below the standard allowable limit of $0.001 \%$ by mass.

Distillation Temperature. This provides a measure range over which a fuel volatizes to a vapor. For petrodiesel, the distillation curve is associated with properties such as viscosity, vapor pressure, heating value, and average molecular weight. Petrodiesel is composed of hundreds of compounds boiling at different temperatures. Biodiesel does not exhibit a distillation curve since the fatty esters comprising it have very similar boiling point under the reduced pressure conditions. The atmospheric boiling point of biodiesel is generally $360^{\circ} \mathrm{C}$ maximum. The distillation temperature of PBD was found to be $242^{\circ} \mathrm{C}$.

The measured fuel properties of PBD were within prescribed ASTM D6751 specifications, thus indicating that PBD is acceptable as a substitute for petrodiesel fuel for diesel engines.

3.2. Emulsion Tendency. Water enters into storage tanks and pipelines from various sources. Whatever the source of water is, whenever it comes in contact with the surface of metal, the surface becomes susceptible to corrosion. Biodiesel plays an important role in determining whether the water will come in contact with the surface and in determining the corrosivity of the water. Due to nonionic nature of biodiesel, it cannot dissolve ionic water. However at low concentrations of water, biodiesel can form an emulsion with the water. The type of emulsion and its stability depends on the type of biodiesel, the ionic content of the water, and the pressure, temperature, and flow rate. Therefore determining the inversion point (w/o becomes $\mathrm{o} / \mathrm{w}$ ) under pipeline operating conditions is necessary. Typical inversion point results of PBD and PO are presented in Figure 3.

From the perspective of corrosion, two types (water in oil $[\mathrm{w} / \mathrm{o}]$ or oil in water $[\mathrm{o} / \mathrm{w}]$ ) of emulsion are important. In w/o emulsion, oil is the continuous phase, and hence it

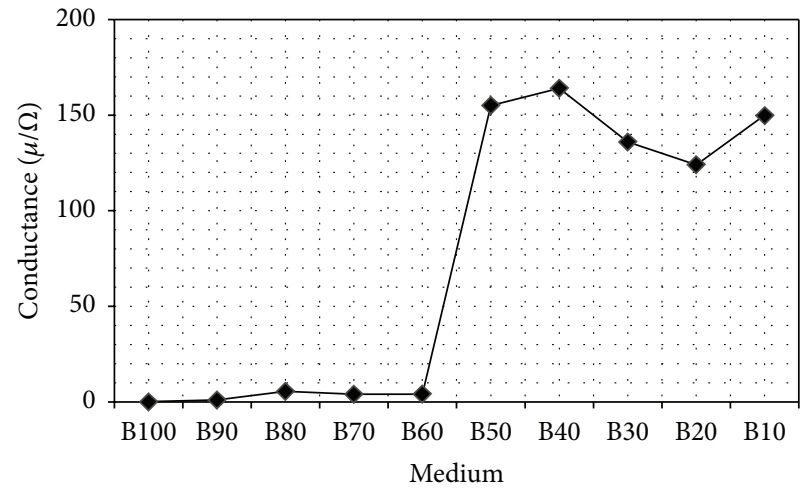

Figure 3: Emulsion inversion point of Pongamia biodiesel.

is noncorrosive. In $\mathrm{o} / \mathrm{w}$ emulsion, water is the continuous phase, and hence it is corrosive. As long as w/o emulsion is present in the pipeline other properties (e.g., wettability and corrosivity) are not important because the water is trapped inside the oil phase. On the other hand, in the presence of $\mathrm{o} / \mathrm{w}$ emulsion, other properties become relevant. The EIPs occurred at 50\% water cut. Corrosive nature of biodiesel seems to be attributed to its free fatty acid components and impurities remaining after processing. In addition, biodiesel is hygroscopic in nature and can absorb moisture from air and thereby can increase the water content [30]. In the presence of free water or o/w emulsion and on a water-wet surface, oil can influence the incidence of corrosion in the water phase. Since EIP for Pongamia biodiesel occurred at 50\% water cut, it is necessary to measure the corrosion rates of various metals in $\mathrm{PBD}$ and its blends with $\mathrm{NaCl}$.

\subsection{Corrosion Rate Measurement}

3.3.1. Static Mass Loss Method. Most corrosion issues of biodiesel have been observed during storage. As the fuel tank is emptied, air enters through the vent pipes to displace the fuel in the tank. Under stagnant conditions, the water drop will form a separate phase at the bottom of the biodiesel container. Therefore the formation of the water drop on the metal surface may push the majority of biodiesel away but leave a thin layer of water biodiesel mixture on the metal surface. This may facilitate the anodic metal oxidation and cathodic reduction of water and dissolved oxygen as well. Hence corrosion rates of the chosen metals in B100, B99, and $\mathrm{NaCl}$ by static mass loss method were determined and presented in Table 3.

Higher corrosion rates were observed in $\mathrm{NaCl}$ for all metals. An addition of $1 \%$ of $3 \%(\mathrm{w} / \mathrm{v}) \mathrm{NaCl}$ solution has increased their corrosion rate when compared to B100. As received fuels are virtually water-free but during storage or use, due to the hygroscopic nature, biodiesel can absorb moisture from atmosphere. Upon exposure of metals into biodiesel, water may condense on metal surface and thereby enhance the corrosion process. The order of corrosion rate for studied metals in B100 was found to be carbon steel $>$ mild steel $>$ brass $>$ copper $>$ aluminium. 
TABLE 3: Mean corrosion rates of various metals under static and flow conditions.

\begin{tabular}{lcccccc}
\hline \multirow{2}{*}{ Metal } & \multicolumn{4}{c}{ Mean corrosion rates (mpy) } \\
& \multicolumn{2}{c}{ B100 } & \multicolumn{2}{c}{ B99 } & \multicolumn{2}{c}{ NaCl } \\
& Static & Flow & Static & Flow & Static & Flow \\
\hline Aluminium & 0.12 & 1.04 & 1.31 & 2.43 & 2.06 & 10.08 \\
Brass & 0.38 & 5.85 & 0.53 & 8.2 & 0.87 & 9.61 \\
Copper & 0.16 & 1.83 & 1.03 & 2.31 & 1.8 & 2.58 \\
Carbon steel & 0.63 & 1.48 & 1.48 & 3.63 & 2.34 & 25.76 \\
Mild steel & 0.43 & 0.78 & 2.36 & 4.08 & 3.72 & 30.31 \\
\hline
\end{tabular}

Aluminium was least corroded (0.12 mpy) in B100, since the water present in the fuel might mitigate the corrosion by contributing to the formation of a protective hydrous oxide surface film such as bayerite $\left(\mathrm{Al}(\mathrm{OH})_{3}\right)$ or boehmite $(\mathrm{AlOOH})$ by the following reactions [31]:

$$
\begin{aligned}
& \mathrm{Al}^{3+}+3 \mathrm{H}_{2} \mathrm{O}+3 \mathrm{e}^{-} \longrightarrow \mathrm{Al}(\mathrm{OH})_{3}+\frac{3}{2} \mathrm{H}_{2} \\
& \mathrm{Al}^{3+}+2 \mathrm{H}_{2} \mathrm{O}+3 \mathrm{e}^{-} \longrightarrow \mathrm{AlOOH}+\frac{3}{2} \mathrm{H}_{2}
\end{aligned}
$$

ASTM D130 in ASTM D6751 and ISO 2160 in EN14214 (copper strip corrosion test standards) are utilized to evaluate the corrosiveness of biodiesel toward a copper surface. This method consists of dipping a strip of copper into the fuel for a specified time and defined temperature to observe the corrosive action of the fuel. The degree of tarnish on the corroded strip correlates with the overall corrosiveness of the fuel sample. This technique is limited in its ability to qualify and distinguish the extent of attack for low corrosive biodiesel [32]. The present study confirmed that the copper strip test alone is not enough to determine the fuel property since the corrosion of ferrous metal was found to be high in PBD compared to other metals. Hence the corrosivity data of various metals in biodiesel should be established in order to confidently use biodiesel without corrosion problems.

3.3.2. Rotating Cage Studies. Table 3 reveals that the corrosion was severe in $\mathrm{NaCl}$ and the least in $\mathrm{B} 100$ which can be justified from the fact that the corrosion rate increases with increase in vortex length [19]. The measured vortex lengths for $\mathrm{NaCl}$ and $\mathrm{B} 100$ are 13.2 and $6.5 \mathrm{~cm}$, respectively. On addition of $1 \%$ of $3 \%(\mathrm{w} / \mathrm{v}) \mathrm{NaCl}$ solution the corrosion rate increased to a small extent when compared to B100. Measured corrosion rates were higher in flow than in static condition for all studied metals in PBD and its blends with $\mathrm{NaCl}$. It has been found that the order of metal corrosion depends on the condition applied. Higher corrosion in the flow condition may be attributed to the presence of relative motion between metal and the fuel [33]. This is due to increased relative movement between the fluid and the wall of the pipe, resulting in mechanical wear and abrasion. This wear eventually results into erosion corrosion, characterized by pit, grooves on the metal surface. In the presence of air or oxygen biodiesel will

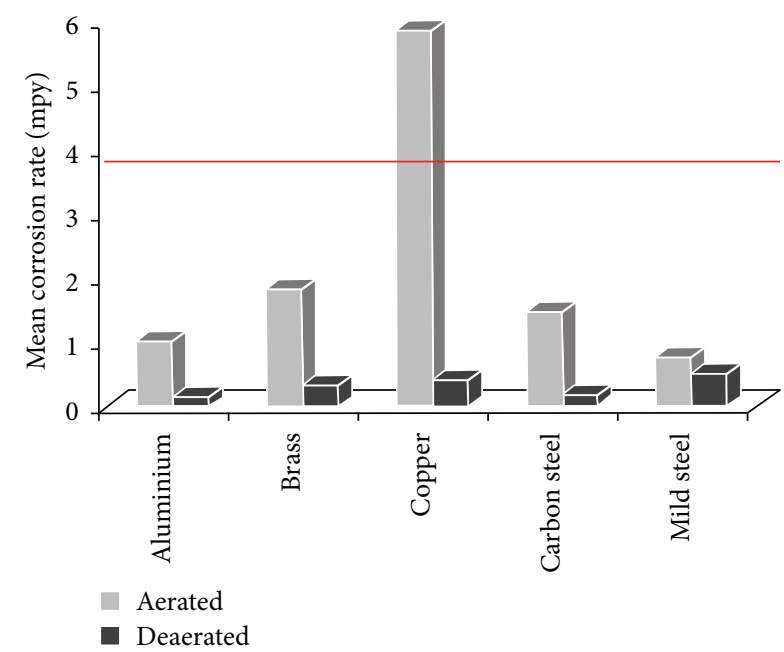

FIGURE 4: Comparison of mean corrosion rates of studied metals in B100 using rotating cage.

be hydrolyzed to alcohol and acid. Presence of alcohol will lead to reduction in flash point and presence of acid will increase total acid number. All of these make methyl ester relatively unstable on storage and cause damage to engine parts. The results obtained for the study carried out under aerated and deaerated conditions using rotating cage are tabulated in Table 4.

Comparison of mean corrosion rates of various metals in B100 under aerated and deaerated conditions has been pictorially represented in Figure 4. A red line at 4 mpy in the figure is the target line for acceptable corrosion rates. It is clear that all metals, except copper under aerated condition, are away below the target lines at all conditions. Dissolved oxygen in biodiesel kinds can ultimately accelerate the corrosion rate. This agreement is supported by the compared corrosion rates of aluminium, brass, copper, carbon steel, and mild steel in $\mathrm{B} 100, \mathrm{~B} 99$, and $\mathrm{NaCl}$ obtained from rotating cage studies under aerated and deaerated conditions (Table 4). The stability of biodiesel depends on the fatty acid profile of the parent feedstock. Biodiesel kinds contain more or less unsaturated fatty acids in their composition, which are susceptible to oxidation reactions accelerated by exposure to oxygen to yield stable products like aldehydes, shorter chain carboxylic acids, insolubles, gum, and sediments. If biodiesel containing these oxidation products is used in the engine, it impairs the engine performance due to fuel filter plugging, injector fouling, and deposit formation in engine, the combustion chamber, and various components of the fuel system [34].

Since copper accelerates oxidation of biodiesel, higher corrosion rate was found in copper than in aluminium, brass, and ferrous metals (Figure 4). According to Feng et al., 1996 [35], in the presence of oxygen, copper can lead to the formation of cuprous oxide $\left(\mathrm{Cu}_{2} \mathrm{O}\right)$. But $\mathrm{Cu}_{2} \mathrm{O}$ is unstable and rapidly it turns to the stable species, $\mathrm{CuO}$. The presence of dissolved water, $\mathrm{CO}_{2}, \mathrm{RCOO}^{-}$, and so forth in biodiesel causes the formation of carbonate and hydroxyl based copper compounds. Fazal et al., 2013 [36], assumed that the copper compounds such as $\mathrm{Cu}_{2} \mathrm{O}, \mathrm{CuO}, \mathrm{CuCO}_{3}$, and $\mathrm{Cu}(\mathrm{OH})_{2}$ 
TABLE 4: Mean corrosion rates of metals in aerated and deaerated conditions.

\begin{tabular}{|c|c|c|c|c|c|c|}
\hline \multirow{3}{*}{ Metal } & \multicolumn{6}{|c|}{ Mean corrosion rates (mpy) } \\
\hline & \multicolumn{2}{|c|}{ B100 } & \multicolumn{2}{|c|}{ B99 } & \multicolumn{2}{|c|}{$\mathrm{NaCl}$} \\
\hline & Aerated & Deaerated & Aerated & Deaerated & Aerated & Deaerated \\
\hline Aluminium & 1.04 & 0.16 & 2.43 & 1.19 & 10.08 & 3.77 \\
\hline Brass & 1.83 & 0.37 & 2.31 & 1.08 & 2.58 & 1.89 \\
\hline Copper & 5.85 & 0.42 & 8.2 & 1.04 & 9.61 & 1.76 \\
\hline Carbon steel & 1.48 & 0.19 & 3.63 & 1.39 & 25.76 & 5.07 \\
\hline Mild steel & 0.78 & 0.52 & 4.08 & 2.02 & 30.31 & 17.68 \\
\hline
\end{tabular}

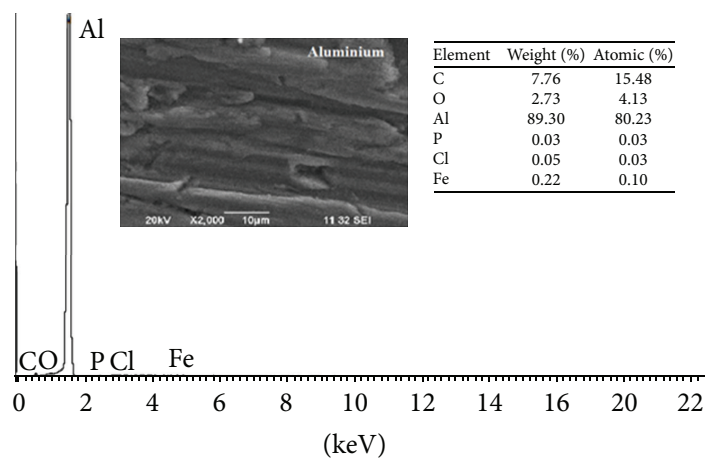

FIGURE 5: SEM image and EDS spectra of aluminium sample immersed in PBD.

are the major constituents formed on the copper surface immersed in palm biodiesel. They observed that dissolved $\mathrm{O}_{2}$, $\mathrm{H}_{2} \mathrm{O}, \mathrm{CO}_{2}$, and $\mathrm{RCOO}^{-}$in biodiesel are associated with the formation of different copper compounds.

3.4. Surface Analysis. The change in surface morphology of aluminium (least corroded) and carbon steel (corroded) after exposure to PBD for $100 \mathrm{~h}$ under static condition was characterized by SEM. The SEM micrographs and the corresponding energy dispersive $\mathrm{X}$-ray spectra of the aluminium and carbon steel samples exposed to PBD are presented in Figures 5 and 6 , respectively. Visually, these micrographs reveal that there was not much damage on aluminium whereas occasional pits were observed on carbon steel. Formation of pits may be due to the corrosive attack of oxygenated compounds present on steel surfaces which has been proved by EDX. The elemental analyses of metal samples immersed in PBD surfaces show the presence of higher percentage of oxygen in carbon steel than in aluminium with their base metal.

The various observations and results of this study would certainly be of immense help to engineers to have a better idea on the corrosion issues and metal compatibility of the biofuels.

\section{Conclusions}

(i) The measured fuel properties of PBD were within prescribed ASTM D6751 specifications, thus indicating

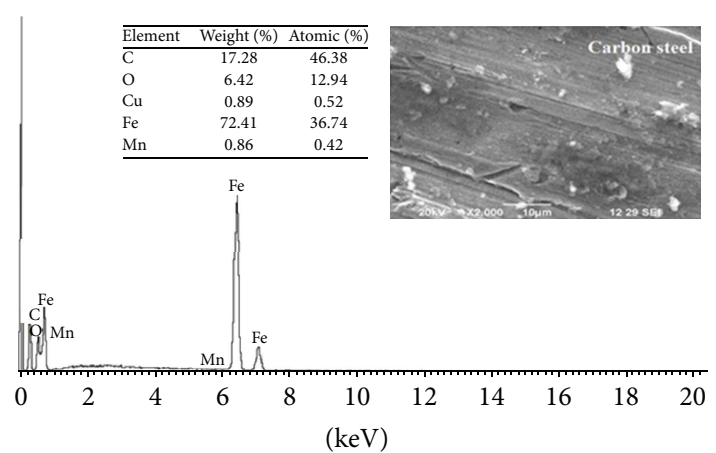

FIgURE 6: SEM image and EDS spectra of carbon steel sample immersed in PBD.

that PBD is acceptable as a substitute for petrodiesel fuel for diesel engines also supported by FT-IR analysis.

(ii) In the presence of free water or $\mathrm{o} / \mathrm{w}$ emulsion and on a water-wet surface, oil can influence the incidence of corrosion in the water phase. EIP for Pongamia biodiesel occurred at $50 \%$ water cut which necessitates measuring the corrosion rates of various metals in PBD and its blends with $\mathrm{NaCl}$.

(iii) The order of corrosion rate for studied metals in PBD was found to be carbon steel $>$ mild steel $>$ brass $>$ copper $>$ aluminium.

(iv) The present study confirmed that the copper strip test alone is not enough to determine the fuel property since the corrosion of ferrous metal was found to be high in PBD compared to other metals. Hence the corrosivity data of various metals in biodiesel should be established in order to confidently use biodiesel without corrosion problems.

(v) Measured corrosion rates were higher in flow than in static condition for all studied metals in PBD and its blends with $\mathrm{NaCl}$. It has been found that the order of metal corrosion depends on the condition applied. Higher corrosion in the flow condition may be attributed to the presence of relative motion between metal and the fuel. 
(vi) Dissolved oxygen in biodiesel kinds can ultimately accelerate the corrosion rate. This agreement is supported by the compared corrosion rates of aluminium, brass, copper, carbon steel, and mild steel in $\mathrm{B} 100, \mathrm{~B} 99$, and $\mathrm{NaCl}$ obtained from rotating cage studies under aerated and deaerated conditions.

(vii) Neat surface morphology and minimum percentage of oxygen on the aluminium surface confirm the least corrosion rate of aluminium under static condition.

\section{Conflict of Interests}

The authors declare that there is no conflict of interests regarding the publication of this paper.

\section{Acknowledgments}

The authors would like to thank the authorities of Avinashilingam University for Women, Coimbatore, Tamil Nadu, India, for providing necessary facilities to carry out this study. The authors would also like to acknowledge the financial support from DST-CURIE in the form of fellowship.

\section{References}

[1] S. A. Raghavendra Prasada and K. V. Suresh, "Pongamia pinnata (karanja) biodiesel as an alternate fuel for diesel engine: a review," Advanced Engineering and Applied Sciences, vol. 4, no. 4, pp. 52-61, 2014.

[2] K. Shikha and C. Y. Rita, "Biodiesel production from non edibleoils: a review," Journal of Chemical and Pharmaceutical Research, vol. 4, no. 9, pp. 4219-4230, 2012.

[3] A. Anand, H. N. Meenakshi, and R. Shyamala, "Study on the impact of Jatropha curcus biodiesel on selected metals," The Ecoscan, vol. 1, pp. 291-294, 2011.

[4] P. T. Scott, L. Pregelj, N. Chen, J. S. Hadler, M. A. Djordjevic, and P. M. Gresshoff, "Pongamia pinnata: an untapped resource for the biofuels industry of the future," BioEnergy Research, vol. 1, no. 1, pp. 2-11, 2008.

[5] N. Sánchez, R. Sánchez, J. M. Encinar, J. F. González, and G. Martínez, "Complete analysis of castor oil methanolysis to obtain biodiesel," Fuel, vol. 147, pp. 95-99, 2015.

[6] G. G. Muciño, R. Romero, A. Ramírez, S. L. Martínez, R. BaezaJiménez, and R. Natividad, "Biodiesel production from used cooking oil and sea sand as heterogeneous catalyst," Fuel, vol. 138, pp. 143-148, 2014.

[7] P. Adewale, M. Dumont, and M. Ngadi, "Recent trends of biodiesel production from animal fat wastes and associated production techniques," Renewable and Sustainable Energy Reviews, vol. 45, pp. 574-588, 2015.

[8] S. A. Shahir, H. H. Masjuki, M. A. Kalam, A. Imran, and A. M. Ashraful, "Performance and emission assessment of dieselbiodiesel, ethanol/bioethanol blend as a fuel in diesel engines: a review," Renewable \& Sustainable Energy Reviews, vol. 4, pp. 62-78, 2015.

[9] B. R. Moser, "Impact of fatty ester composition on low temperature properties of biodiesel petroleum diesel blends," Fuel, vol. 115, pp. 500-506, 2014.

[10] M. Gülüm and A. Bilgin, "Density, flash point and heating value variations of corn oil biodiesel-diesel fuel blends," Fuel Processing Technology, vol. 134, pp. 456-464, 2015.
[11] K. A. Sorate and P. V. Bhale, "Biodiesel properties and automotive system compatibility issues," Renewable and Sustainable Energy Reviews, vol. 41, pp. 777-798, 2015.

[12] A. S. M. A. Haseeb, M. A. Fazal, M. I. Jahirul, and H. H. Masjuki, "Compatibility of automotive materials in biodiesel: a review," Fuel, vol. 90, no. 3, pp. 922-931, 2011.

[13] D. Mizuno, S. Suzuki, S. Fujita, and N. Hara, "Corrosion monitoring and materials selection for automotive environments by using Atmospheric Corrosion Monitor (ACM) sensor," Corrosion Science, vol. 83, pp. 217-225, 2014.

[14] J. C. Cazarolli, R. Guzatto, D. Samios, M. D. C. R. Peralba, E. H. D. S. Cavalcanti, and F. M. Bento, "Susceptibility of linseed, soybean, and olive biodiesel to growth of the deteriogenic fungus Pseudallescheria boydii," International Biodeterioration \& Biodegradation, vol. 95, pp. 364-372, 2014.

[15] S. Chen, P. Wang, and D. Zhang, "Corrosion behavior of copper under biofilm of sulfate-reducing bacteria," Corrosion Science, vol. 87, pp. 407-415, 2014.

[16] J. W. Sowards and E. Mansfield, "Corrosion of copper and steel alloys in a simulated underground storage-tank sump environment containing acid-producing bacteria," Corrosion Science, vol. 87, pp. 460-471, 2014.

[17] B. Singh, J. Korstad, and Y. C. Sharma, "A critical review on corrosion of compression ignition (CI) engine parts by biodiesel and biodiesel blends and its inhibition," Renewable and Sustainable Energy Reviews, vol. 16, no. 5, pp. 3401-3408, 2012.

[18] J. Pullen and K. Saeed, "An overview of biodiesel oxidation stability," Renewable and Sustainable Energy Reviews, vol. 16, no. 8, pp. 5924-5950, 2012.

[19] H. N. Meenakshi, A. Anisha, R. Shyamala, R. Saratha, and S. Papavinasam, "Corrosion of metals in biodiesel from Pongamia pinnata," in Proceedings of the CORROSION 2010, NACE Paper \# 10076, San Antonio, Tex, USA, March 2010.

[20] S. Papavinasam, A. Doiron, T. Panneerselvam, and R. W. Revie, "Effect of hydrocarbons on the internal corrosion of oil and gas pipelines," Corrosion, vol. 63, no. 7, pp. 704-712, 2007.

[21] S. Papavinasam, R. W. Revie, M. Attard, A. Demoz, J. C. Donini, and K. Michaelian, "Rotating cage-top ranked methodology for inhibitor evaluation and qualification for pipeline applications," NACE Corrosion 01061, 2001.

[22] M. H. Parameswaran, A. Anand, and S. R. Krishnamurthy, "A comparison of corrosion behavior of copper and its alloy in Pongamia pinnata oil at different conditions," Journal of Energy, vol. 2013, Article ID 932976, 4 pages, 2013.

[23] H. H. Uhlig, The Effect of Salt Concentration on the Corrosion Rate of Carbon Steel, The Corrosion Handbook, John Wiley \& Sons, New York, NY, USA, 1948.

[24] S. Papavinasam, M. Attard, R. Revie, and J. Bojes, "Rotating cage: a compact laboratory methodology for simultaneously evaluating corrosion inhibition and drug reducing properties of chemicals," in Proceedings of the CORROSION 2002, NACE Paper \# 2271, Denver, Colo, USA, April 2002.

[25] M. Shah, S. Ali, M. Tariq, N. Khalid, F. Ahmad, and M. A. Khan, "Catalytic conversion of jojoba oil into biodiesel by organotin catalysts, spectroscopic and chromatographic characterization," Fuel, vol. 118, pp. 392-397, 2014.

[26] P. D. Patil, H. Reddy, T. Muppaneni et al., "Power dissipation in microwave-enhanced in situ transesterification of algal biomass to biodiesel," Green Chemistry, vol. 14, no. 3, pp. 809-818, 2012. 
[27] D. Kane and S. Papavinasam, "Corrosion and SCC issues in fuel ethanol and biodiesel corrosion," in Proceedings of the CORROSION 2009, NACE Paper \# 09528, Atlanta, Ga, USA, March 2009.

[28] M. Naik, L. C. Meher, S. N. Naik, and L. M. Das, "Production of biodiesel from high free fatty acid Karanja (Pongamia pinnata) oil," Biomass and Bioenergy, vol. 32, no. 4, pp. 354-357, 2008.

[29] U. Rashid, F. Anwar, and G. Knothe, "Evaluation of biodiesel obtained from cottonseed oil," Fuel Processing Technology, vol. 90, no. 9, pp. 1157-1163, 2009.

[30] M. A. Fazal, A. S. M. A. Haseeb, and H. H. Masjuki, "Comparative corrosive characteristics of petroleum diesel and palm biodiesel for automotive materials," Fuel Processing Technology, vol. 91, no. 10, pp. 1308-1315, 2010.

[31] I. J. Park, Y. H. Yoo, J. G. Kim, D. H. Kwak, and W. S. Ji, "Corrosion characteristics of aluminum alloy in bio-ethanol blended gasoline fuel: part 2. The effects of dissolved oxygen in the fuel," Fuel, vol. 90, no. 2, pp. 633-639, 2011.

[32] A. R. Sadrolhosseini, M. M. Moksin, W. M. M. Yunus, and Z. A. Talib, "Measuring the low corrosiveness of biodiesel: application of a surface plasmon resonance sensor using a copper layer," Corrosion, vol. 68, no. 2, Article ID 025005, 2012.

[33] G. Schmitt, W. Bruckhoff, K. Faessler, and G. Blummel, "Flow loop vs rotating probes-experimental results and service application," Materials Performance, vol. 30, no. 2, pp. 85-92, 1991.

[34] S. Jain and M. P. Sharma, "Prospects of biodiesel from Jatropha in India: a review," Renewable and Sustainable Energy Reviews, vol. 14, no. 2, pp. 763-771, 2010.

[35] Y. Feng, W.-K. Teo, K.-S. Siow, K.-L. Tan, and A.-K. Hsieh, “The corrosion behaviour of copper in neutral tap water. Part I: corrosion mechanisms," Corrosion Science, vol. 38, no. 3, pp. 369-385, 1996.

[36] M. A. Fazal, A. S. M. A. Haseeb, and H. H. Masjuki, "Corrosion mechanism of copper in palm biodiesel," Corrosion Science, vol. 67, pp. 50-59, 2013. 

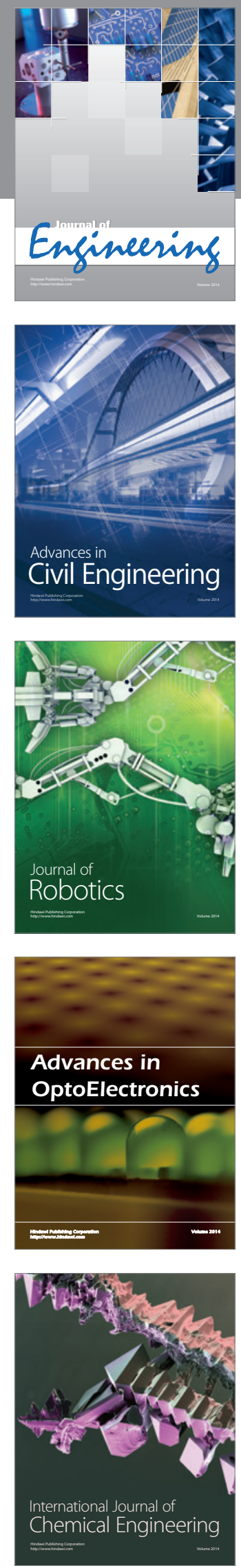

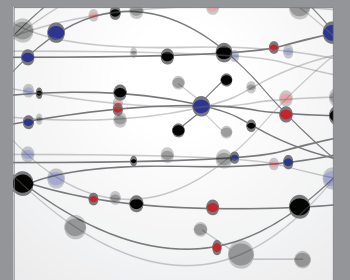

The Scientific World Journal
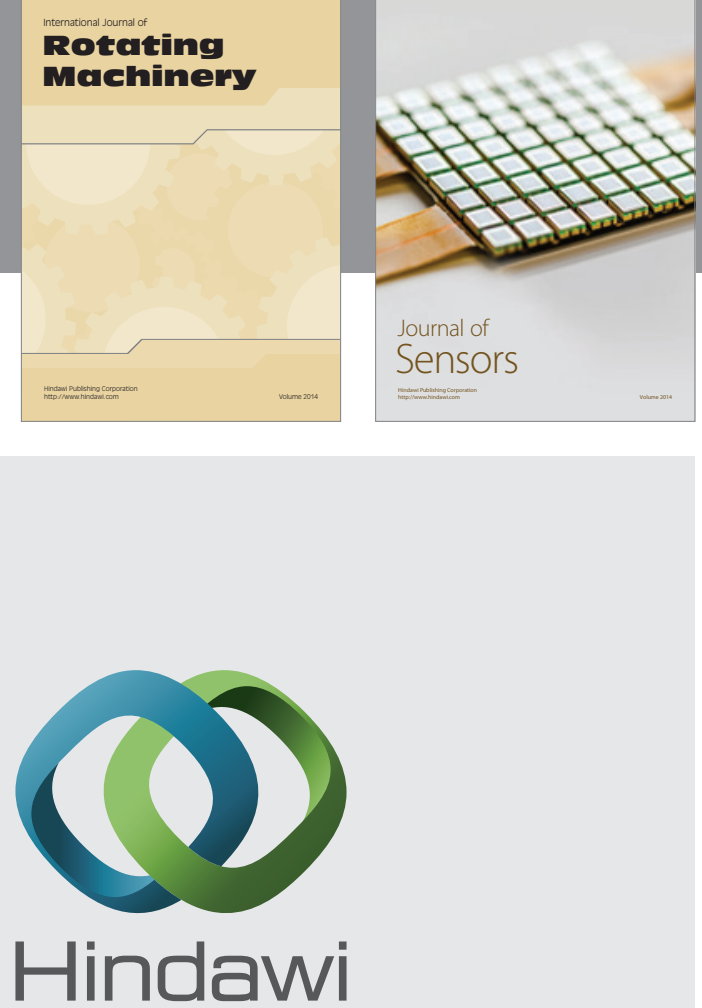

Submit your manuscripts at http://www.hindawi.com
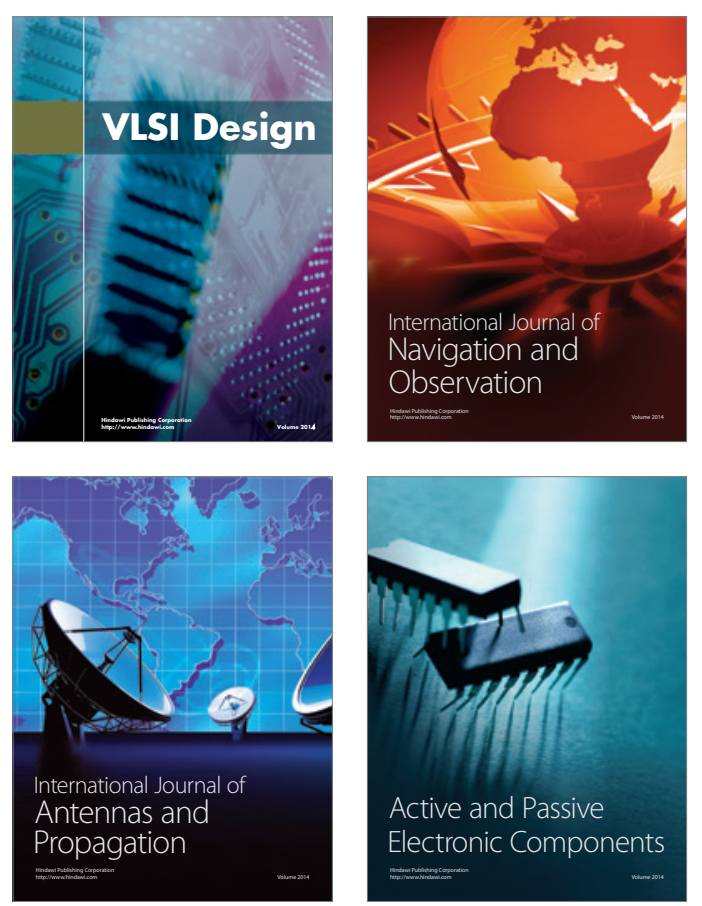
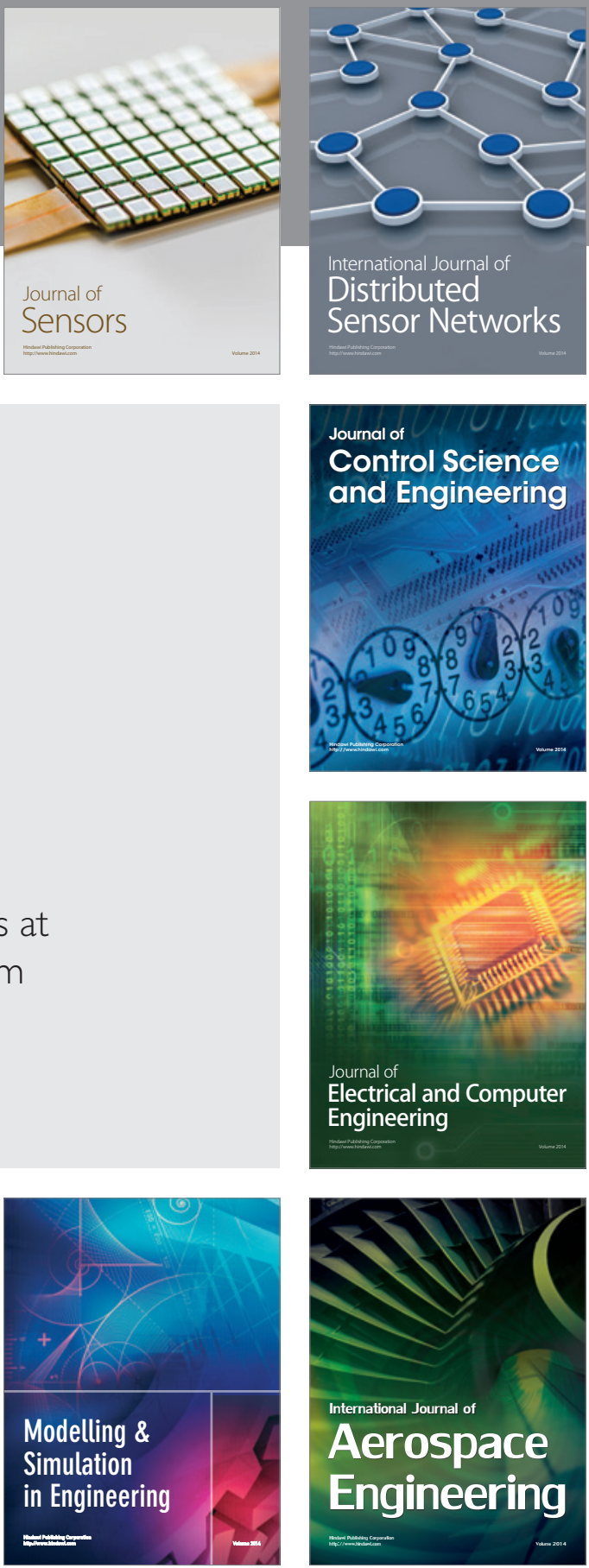

Journal of

Control Science

and Engineering
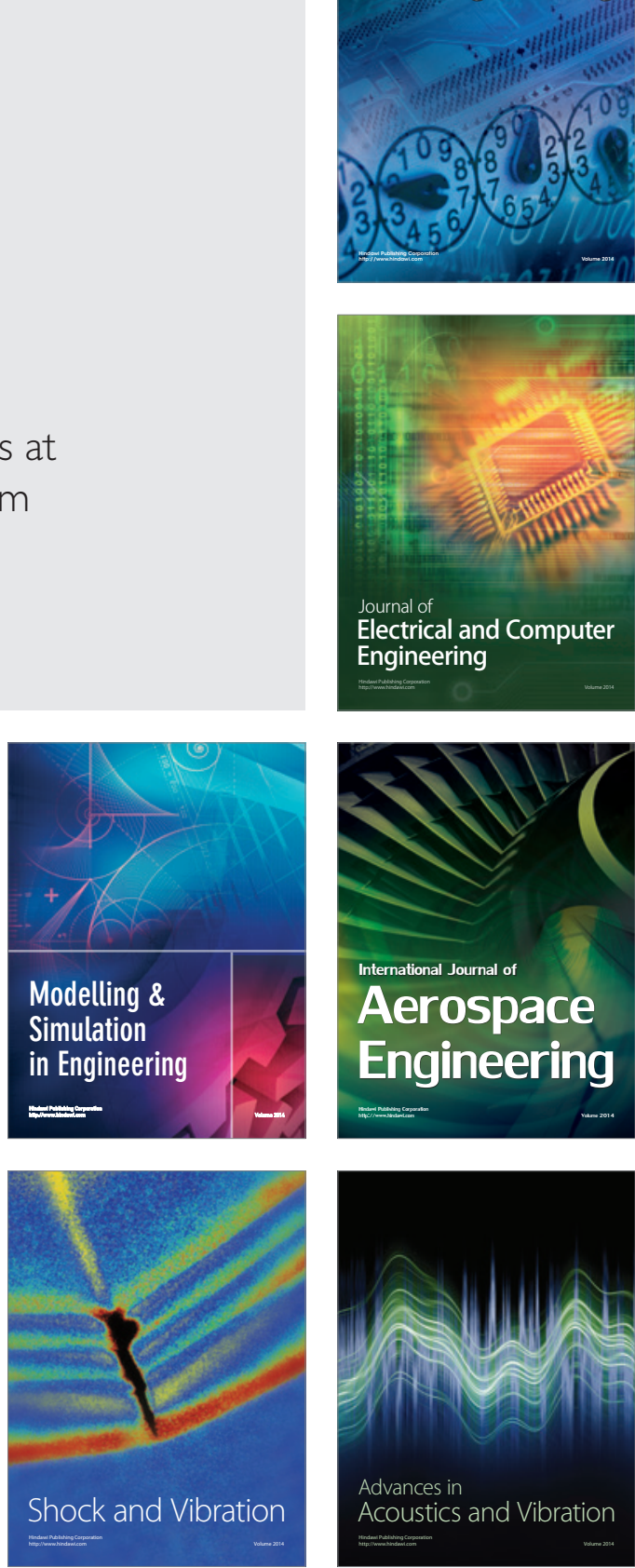